Revue bibliographique pour le domaine irano-aryen

\title{
Farhad Khosrokhavar, Amir Nikpey. Avoir vingt ans au pays des ayatollahs
}

\section{Alice Bombardier}

\section{OpenEdition}

1 Journals

\section{Édition électronique}

URL : http://journals.openedition.org/abstractairanica/41044

DOI : 10.4000/abstractairanica.41044

ISSN : 1961-960X

Éditeur :

CNRS (UMR 7528 Mondes iraniens et indiens), Éditions de l'IFRI

\section{Édition imprimée}

Date de publication : 1 décembre 2013

ISSN : 0240-8910

\section{Référence électronique}

Alice Bombardier, «Farhad Khosrokhavar, Amir Nikpey. Avoir vingt ans au pays des ayatollahs », Abstracta Iranica [En ligne], Volume 32-33 | 2013, document 457, mis en ligne le 01 juillet 2016, consulté le 27 septembre 2020. URL : http://journals.openedition.org/abstractairanica/41044 ; DOI : https://doi.org/10.4000/abstractairanica.41044

Ce document a été généré automatiquement le 27 septembre 2020.

Tous droits réservés 


\title{
Farhad Khosrokhavar, Amir Nikpey. Avoir vingt ans au pays des ayatollahs
}

\author{
Alice Bombardier
}

\section{RÉFÉRENCE}

Farhad Khosrokhavar, Amir Nikpey. Avoir vingt ans au pays des ayatollahs. Paris, Robert

Laffont, 2009, $406 \mathrm{p}$.

1 Ce livre est le fruit d'une étude sociologique menée entre 2002 et 2004 à Téhéran, Qazvin mais surtout dans la ville sainte de Qom. Cette ville de taille moyenne est connue en Iran pour son conservatisme religieux et le puissant contrôle social qui y règne. Assisté notamment par Amīr Nīkpey, Farhād HosroHāavar focalise ici son attention sur la jeune génération post-révolutionnaire (19-29 ans). L'enquête est basée sur cinq thématiques principales, qui forment les grands axes du livre: le sentiment religieux, les rapports familiaux et de genre, les projets individuels, l'image de soi et de l'autre, les loisirs. De nombreux pans d'entretiens sont systématiquement rapportés.

2 "Acteur de sa vie ", tel est le concept avancé pour qualifier la subjectivité à polarités multiples de ces jeunes en voie d'émancipation. Mais le livre est surtout intéressant pour son analyse des différentes modalités de sécularisation observables à Qom (sectorielle, différentielle ou contradictoire). Entre bricolages, ambivalences, affirmation ou culpabilité, le rapport à la religion de ces jeunes très encadrés par le clergé shiite, évolue. Les conclusions de l'enquête aspirent également à faire comprendre les tentatives d'aménagement de l'islam, opérées en Europe, par les minorités musulmanes. 


\section{AUTEURS}

ALICE BOMBARDIER

Paris 